\title{
Determining Nutritive Value of Cereal Crop Residues and Lentil (Lens esculanta) Straw for Ruminants
}

\author{
Eyob Haile1, Mathew Gicheha ${ }^{2 *}$, Francis K. Njonge ${ }^{2}$, Goitom Asgedom¹ \\ ${ }^{1}$ Department of Animal Sciences, Hamelmalo Agricultural College, Keren, Eritrea \\ ${ }^{2}$ Department of Animal Sciences, Jomo Kenyatta University of Agriculture and Technology, Nairobi, Kenya \\ Email: ^gicheham@jkuat.ac.ke, *gichehag@yahoo.com
}

How to cite this paper: Haile, E., Gicheha, M., Njonge, F.K. and Asgedom, G. (2017) Determining Nutritive Value of Cereal Crop Residues and Lentil (Lens esculanta) Straw for Ruminants. Open Journal of Animal Sciences, 7, 19-29.

http://dx.doi.org/10.4236/ojas.2017.71003

Received: November 8, 2016

Accepted: December 26, 2016

Published: December 29, 2016

Copyright $\odot 2017$ by authors and Scientific Research Publishing Inc. This work is licensed under the Creative Commons Attribution International License (CC BY 4.0).

http://creativecommons.org/licenses/by/4.0/

\begin{abstract}
The chemical composition and in situ dry matter (DM) and organic matter (OM) degradability of seven different cereal crop residues were evaluated in this study. They included the Sorghum stovers (SS) and its threshed head residues (STH), millet stovers (MS) and its threshed head residues (MTH), corn stover (CS), wheat (WS) and barley (BS) straws. A legume crop residue (lentil, Lens esculanta, straw; LS) was included for comparison with the cereal crop residues. The CS was high $(\mathrm{P}<0.05)$ in crude protein $(\mathrm{CP})$ and acid detergent lignin $(\mathrm{ADL})$ and the lowest $(\mathrm{P}<0.05)$ in Neutral Detergent Fibre (NDF) and acid detergent fibre (ADF) when compared to the amounts in SS and MS. It was found out that LS had higher $(\mathrm{P}<0.05) \mathrm{CP}, \mathrm{ADL}, \mathrm{ME}$ and low $(\mathrm{P}<0.05) \mathrm{NDF}$ and ADF than the cereal crop residues. There were differences in digestible DM (DMD) at various incubation times both between and within the feed samples. The DM and OM $a, c$ fraction were highest $(\mathrm{P}<0.05)$ for LS when compared to all the cop residues evaluated. The BS and MS had the lowest effective degradability $(\mathrm{ED}) \mathrm{DM}$ at 0.02 and $0.05(\mathrm{P}<0.05)$ rates of passage, while the LS had the highest. The chemical composition and degradability of different crop residues found in Eritrea indicate the potential the residues have in supplementing grazing animals.
\end{abstract}

\section{Keywords}

Cereal Crop Residues, Chemical Composition, Degradability, Nutritive Value

\section{Introduction}

Grazed livestock production systems in many developing countries are constrained by the quality and quantity of feed resources available at any given time of the year [1] especially in dry land systems where feed demand and supply fluctuates within and be- 
tween years as a result of climatic variability [2]. In the extensive grazed livestock production systems of Eritrea, animals are grazed on poor quality unimproved pastures which results in poor animal productivity [3]. However, studies [4] [5] [6] [7] have shown that crop residues and agro-industrial by-products can be used to supplement the grazing animals and that the nutritional value of the feedstuffs can be enhanced using tested treatment procedures [8] [9] [10] [11].

A survey carried out in Eritrea indicated that the country produced up to 1.2 million tons of crop residues each year [12] which justified a study of their potential use in livestock production. Understanding the chemical and nutritive characteristics of the crop residues would aid in designing optimal utilization strategies at farm and/or national levels. Furthermore, these characteristics indicate the feeding value of the feedstuffs. In Eritrea, the information on the chemical composition and nutritive value of available crop residues is scanty. Therefore, this study was undertaken to determine the chemical composition and ruminal degradation kinetics of seven different cereal crop residues and a legume straw. Since the cell-wall carbohydrates are the most important components of the straws, an efficient microbial digestion in the rumen is crucial for their utilization in ruminant feeding. In recent years, a number of studies have suggested that degradation characteristics of these types of feeds in the rumen will provide a useful basis for the evaluation of their nutritive value [13] [14] [15].

\section{Material and Methods}

\subsection{Sample Collection}

A total of eight cereal crop residues found in different agricultural zones in Eritrea were collected for analysis. They included the Sorghum stovers (SS) and its threshed head residues (STH), millet stovers (MS) and its threshed head residues (MTH), corn stover (CS), barley (BS) and wheat (WS) straws and Lentil, Lens esculanta, straw (LS). The LS was included for the purposes of comparing the chemical and nutritional characteristics of legumes with that of the cereal crop residues. Samples of each collected feedstuff were grounded for chemical and in situ procedures. To avoid bias resulting from different crops growing conditions in different zones in Eritrea, only those from the same zone were pooled. The results for the same residue from similar zones were tested for any significant difference in chemical and nutritional characteristics before obtaining their average. Where differences were found for similar residue from different zones, results were considered and discussed differently.

\subsection{Chemical Analysis}

The dry matter (DM) and organic matter (OM) were determined according to the standard methods [16]. The ash content was determined by ashing samples in a muffle furnace at $550^{\circ} \mathrm{C}$ for $6 \mathrm{~h}$ while the nitrogen $(N)$ content was determined using Kjeldahl method [16]. The crude protein $(C P)$ was calculated as:

$$
C P=N * 6.25
$$

The crude fiber $(C F)$ and ether extract $(E E)$ were determined by the methods described in the [16]. The nitrogen free extract (NFE) was determined as:

$$
N F E=[100-(C P+E E+C F+A s h)]
$$


The cell wall components were determined according to [17].

\subsection{In Situ Degradation Procedures}

The nylon bag procedure described by [18] was used in determining the nutritive value of the crop residues considered in this study. In all, a $5 \mathrm{~g}$ of dried sample of the crop residues were milled through a $3 \mathrm{~mm}$ screen. The sample was then weighed in nylon bags $(16 \times 8 \mathrm{~cm}$, pore size 45 to $60 \mu \mathrm{m})$ which were then incubated in the rumen of two cattle fitted with rumen cannula. The research adhered to the guidelines proposed in the Guide for the Care and Use of Agricultural Animals in Agricultural Research and Teaching [19].

The bags were withdrawn at 4, 8, 16, 24, 48, 72 and $96 \mathrm{~h}$ intervals following insertion. They were subsequently rinsed with cold water until it became clear. This was followed by drying of the bags and samples at $60^{\circ} \mathrm{C}$ for $48 \mathrm{~h}$. The soluble fraction $(0 \mathrm{~h})$ value was obtained by soaking two bags of the sample in warm water $\left(38^{\circ} \mathrm{C}\right)$ bath for $1 \mathrm{~h}$ which was then followed by washing in cold water for $15 \mathrm{~min}$ in a washing machine. The samples were then dried for $48 \mathrm{~h}$ at $60^{\circ} \mathrm{C}$. The rumen degradation kinetics of DM and $\mathrm{OM}$ were calculated using the exponential equation by [18] as:

$$
P=a+b\left(1-e^{-c t}\right)
$$

where $p$ is the percentage degradability for response variable at time $t$ which is the time relative to incubation (hours), a represents the highly soluble and readily degradable fraction (\%), $b$ the insoluble and slowly degradable fraction (\%), $c$ is the rate constant for degradation $\left(\mathrm{h}^{-1}\right)$ and $e$ is the natural logarithm base (2.7182). The effective degradability $(E D)$ of the $\mathrm{DM}$ and $\mathrm{OM}$ of each sample was determined using the equation proposed by [20]:

$$
E D=a+\frac{(b * c)}{(c+k)}
$$

where parameters $a, b$ and $c$ are as previously defined while $k$ is the rate constant of passage $\left(\mathrm{h}^{-1}\right)$ which was assumed to be $0.02,0.05$ and 0.08 per hour [20] (The metabolisable Energy $(M E)$ content was estimated using equation described by [20] as):

$$
M E(\mathrm{MJ} / \mathrm{kg} D M)=2.27563+0.1073 D M D
$$

where, $D M D$ is rumen dry matter degradability at $48 \mathrm{~h}$ of incubation.

\subsection{Statistical Analysis}

Data on chemical composition and degradation characteristics were subjected to analysis of variance while the least significant differences (LSD) test was used in all cases to compare the samples means. Differences were accepted when $\mathrm{p} \leq 0.05$.

\section{Results}

\subsection{Chemical Composition}

Results for the chemical composition analysis of the crop residues are presented in $\mathrm{Ta}$ ble 1. The DM content of the residue was generally high falling between $90.6 \%$ in CS and $91.9 \%$ in SS. Similar trend was observed in the OM content with the highest value 
Table 1. Chemical composition of crop residues (\% DM).

\begin{tabular}{|c|c|c|c|c|c|c|c|c|c|}
\hline \multirow{2}{*}{ Nutrients ${ }^{2}$} & \multicolumn{8}{|c|}{ Crop Residues ${ }^{1}$} & \multirow[t]{2}{*}{ SEM } \\
\hline & SS & STH & MS & MTH & CS & WS & BS & LS & \\
\hline $\mathrm{DM}(\%)$ & $91.9^{\mathrm{a}}$ & $91.4^{\mathrm{bd}}$ & $91.5^{\mathrm{b}}$ & $91.3^{\mathrm{b}}$ & $90.6^{\mathrm{c}}$ & $91.3^{\mathrm{b}}$ & $91.01^{\mathrm{d}}$ & $91.5^{\mathrm{b}}$ & 1 \\
\hline \multicolumn{10}{|c|}{ Chemical composition (\%) } \\
\hline Ash & $8.6^{\mathrm{c}}$ & $8.7^{\mathrm{c}}$ & $12.2^{\mathrm{d}}$ & $5.11^{\mathrm{e}}$ & $7.59^{\mathrm{b}}$ & $9.70^{\mathrm{a}}$ & $13.02^{\mathrm{f}}$ & $9.99^{\mathrm{a}}$ & 0.61 \\
\hline $\mathrm{OM}$ & $91.4^{\mathrm{a}}$ & $91.2^{\mathrm{a}}$ & $87.8^{\mathrm{c}}$ & $94.9^{\mathrm{b}}$ & $92.4^{\mathrm{d}}$ & $90.3^{\mathrm{e}}$ & $86.0^{\mathrm{f}}$ & $90.01^{\mathrm{e}}$ & 0.61 \\
\hline $\mathrm{CP}$ & $3.6^{\mathrm{b}}$ & $6.73^{\mathrm{d}}$ & $3.81^{\mathrm{b}}$ & $10.7^{\mathrm{c}}$ & $7.68^{e}$ & $7.45^{\mathrm{e}}$ & $6.71^{\mathrm{d}}$ & $9.40^{\mathrm{f}}$ & 0.59 \\
\hline $\mathrm{EE}$ & $1.10^{\mathrm{ab}}$ & $1.48^{\mathrm{b}}$ & $5.40^{\mathrm{c}}$ & $2.47^{\mathrm{d}}$ & $0.82^{\mathrm{a}}$ & $1.10^{\mathrm{ab}}$ & $1.43^{\mathrm{b}}$ & $3.82^{\mathrm{e}}$ & 0.39 \\
\hline NFE & $51.3^{\mathrm{a}}$ & $56.01^{\mathrm{b}}$ & $32.2^{\mathrm{c}}$ & $66.4^{\mathrm{d}}$ & $45.6^{\mathrm{e}}$ & $41.7^{\mathrm{f}}$ & $37.1^{\mathrm{g}}$ & $40.5^{\mathrm{f}}$ & 2.69 \\
\hline $\mathrm{CF}$ & $35.4^{\mathrm{c}}$ & $27.0^{\mathrm{b}}$ & $46.5^{\mathrm{a}}$ & $15.3^{\mathrm{d}}$ & $38.3^{\mathrm{e}}$ & $40.05^{\mathrm{f}}$ & $41.7^{\mathrm{g}}$ & $36.3^{c}$ & 2.36 \\
\hline $\mathrm{NDF}$ & $74.1^{\mathrm{a}}$ & $76.8^{\mathrm{b}}$ & $79.3^{c}$ & $62.5^{\mathrm{d}}$ & $66.4^{\mathrm{e}}$ & $71.9^{f}$ & $73.8^{\mathrm{a}}$ & $52.0^{\mathrm{h}}$ & 2.16 \\
\hline $\mathrm{ADF}$ & $46.6^{\mathrm{d}}$ & $31.5^{\mathrm{c}}$ & $53.2^{\mathrm{a}}$ & $20.6^{\mathrm{b}}$ & $37.0^{\mathrm{e}}$ & $43.9^{\mathrm{f}}$ & $46.7^{g}$ & $32.5^{\mathrm{c}}$ & 2.56 \\
\hline $\mathrm{ADL}$ & $6^{\mathrm{ab}}$ & $5.48^{\mathrm{a}}$ & $10.4^{\mathrm{c}}$ & $7.60^{\mathrm{d}}$ & $18.3^{\mathrm{e}}$ & $6.08^{\mathrm{ab}}$ & $6.78^{\text {bd }}$ & $19.1^{\mathrm{e}}$ & 1.36 \\
\hline $\begin{array}{c}\mathrm{ME}(\mathrm{MJ} / \mathrm{kg} \\
\mathrm{DM})\end{array}$ & $7.05^{c}$ & $7.83^{\mathrm{b}}$ & $6.64^{\mathrm{e}}$ & $8.51^{\mathrm{d}}$ & $7.14^{c}$ & $6.80^{\text {ce }}$ & $6.32^{\mathrm{e}}$ & $8.39^{\mathrm{d}}$ & 0.2 \\
\hline
\end{tabular}

Means within the same row with different superscript are significantly different $(\mathrm{P}<0.05)$. ${ }^{1}$ See text for the description of the crop residues. ${ }^{2}$ See text for the description of the nutrients; the values for the Ash, OM, CP, EE, NFE, CF, $\mathrm{NDF}, \mathrm{ADL}$ are presented as percent of the DM content.

of $94.9 \%$ being recorded from MTH and the lowest being $86.0 \%$ from BS. There were minor differences in chemical and nutritional characteristics of samples from different zones and therefore the results presented were obtained from averaging the data across zones for the same crop residue.

The ash content varied from a low of 5.11\% from MTH to a high of $13.02 \%$ in BS. The CS had significantly higher $(\mathrm{P}<0.05) \mathrm{CP}, \mathrm{ADL}$ and lower $(\mathrm{P}<0.05) \mathrm{NDF}$ and ADF than the SS and MS. The WS contained higher $(\mathrm{P}<0.05) \mathrm{CP}$ than BS. The STH and MTH were found to have higher $(\mathrm{P}<0.05) \mathrm{CP}, \mathrm{ME}$ and lower $(\mathrm{P}<0.05) \mathrm{CF}$ and $\mathrm{ADF}$ content than SS and MS. It was generally observed that there was more $(\mathrm{P}<0.05)$ $\mathrm{CP}, \mathrm{ADL}, \mathrm{ME}$ and low $(\mathrm{P}<0.05) \mathrm{NDF}$ and ADF in the legume straw than in cereal crop straws/stovers. The EE was highest $(\mathrm{P}<0.05)$ in MS and lowest in CS while NFE was highest $(\mathrm{P}<0.05)$ in MTH and lowest in MS.

\subsection{In Situ Degradability}

\subsubsection{Dry Matter Degradability (DMD)}

Dry matter degradability (DMD) of crop residues is presented in Table 2. The SS, CS and WS had higher $(\mathrm{P}<0.05)$ level of degradability than MS and BS in all the incubation times.

The percentage DMD in STH and MTH was lower $(\mathrm{P}<0.05)$ at 4 and $8 \mathrm{~h}$ than SS and MS, whereas it was higher $(\mathrm{P}<0.05)$ for the same residues. The legume straw had higher $(\mathrm{P}<0.05) \mathrm{DMD}$ at $0,4,8,16$, and $24 \mathrm{~h}$ than all the cereal crop residues. It is notable that an increase in the incubation time led to increase in DMD and that the DMD amongst different crop residues varied with the incubation time. However, it was 
Table 2. In situ dry matter degradability of crop residues (\% DMD)

\begin{tabular}{cccccccccc}
\hline & \multicolumn{7}{c}{ Time of Incubation in the Rumen (Hrs.) } & & SEM \\
\cline { 2 - 10 } $\begin{array}{c}\text { Crop } \\
\text { residues }\end{array}$ & $\mathbf{0}$ & $\mathbf{4}$ & $\mathbf{8}$ & 16 & 24 & $\mathbf{4 8}$ & 72 & 96 \\
\hline SS & $20.4^{\mathrm{h}}$ & $24.6^{\mathrm{ab}}$ & $28.2^{\mathrm{i}}$ & $33.9^{\mathrm{ce}}$ & $38.4^{\mathrm{dj}}$ & $44.5^{\mathrm{g}}$ & $46.6^{\mathrm{gk}}$ & $46.6^{\mathrm{gk}}$ & 0.33 \\
STH & $14.8^{\mathrm{g}}$ & $18.7^{\mathrm{cg}}$ & $21.9^{\mathrm{ch}}$ & $35.3^{\mathrm{be}}$ & $41.5^{\mathrm{dfi}}$ & $51.8^{\mathrm{a}}$ & $56.1^{\mathrm{a}}$ & $56.1^{\mathrm{a}}$ & 0.73 \\
MS & $16.6^{\mathrm{fg}}$ & $22.06^{\mathrm{bh}}$ & $26.2^{\mathrm{ci}}$ & $30.8^{\mathrm{ed}}$ & $34.1^{\mathrm{j}}$ & $40.7^{\mathrm{k}}$ & $43.1^{\mathrm{kl}}$ & $43.1^{\mathrm{kl}}$ & 0.35 \\
MTH & $17.8^{\mathrm{ef}}$ & $18.8^{\mathrm{eg}}$ & $20.7^{\mathrm{eh}}$ & $30.5^{\mathrm{bcd}}$ & $47.6^{\mathrm{i}}$ & $58.1^{\mathrm{j}}$ & $62.2^{\mathrm{jm}}$ & $62.2^{\mathrm{ajm}}$ & 0.70 \\
CS & $21.03^{\mathrm{h}}$ & $24.9^{\mathrm{a}}$ & $27.9^{\mathrm{i}}$ & $34.3^{\mathrm{bcd}}$ & $39.1^{\mathrm{fj}}$ & $44.9^{\mathrm{g}}$ & $47.4^{\mathrm{k}}$ & $47.9^{\mathrm{k}}$ & 0.102 \\
WS & $19.07^{\mathrm{eh}}$ & $22.2^{\mathrm{bh}}$ & $24.6^{\mathrm{chi}}$ & $29.9^{\mathrm{bcd}}$ & $34.9^{\mathrm{fj}}$ & $42.2^{\mathrm{gk}}$ & $42.3^{\mathrm{kl}}$ & $42.4^{\mathrm{k}}$ & 0.61 \\
BS & $16.76^{\mathrm{fg}}$ & $22.1^{\mathrm{bf}}$ & $24.4^{\mathrm{bci}}$ & $28.6^{\mathrm{bcd}}$ & $32.3^{\mathrm{j}}$ & $37.7^{\mathrm{k}}$ & $39.8^{1}$ & $39.8^{\mathrm{l}}$ & 0.69 \\
LS & $24.4^{\mathrm{c}}$ & $30.6^{\mathrm{d}}$ & $34.3^{\mathrm{d}}$ & $40^{\mathrm{f}}$ & $46.5^{\mathrm{i}}$ & $56.9^{\mathrm{jm}}$ & $59.8^{\mathrm{am}}$ & $59.8^{\mathrm{am}}$ & 0.56 \\
SEM & 0.76 & 0.95 & 1.09 & 1.001 & 1.47 & 1.86 & 2.12 & 2.12 & \\
\hline
\end{tabular}

Means within the same row with different superscript are significantly different $(P<0.05)$. Means within the same column with different superscript are significantly different $(\mathrm{P}<0.05) .{ }^{1}$ See text for the description of the crop residues.

observed that there was no significant difference $(\mathrm{P}<0.05)$ in DMD after $48 \mathrm{~h}$ amongst all the residues.

\subsubsection{Organic Matter Degradability (OMD)}

The organic matter degradability (OMD) of crop residues is presented in Table 3. It varied amongst residues and incubation times. However, the percentage OMD within the respective crop residues was not significantly different $(\mathrm{P}<0.05)$ after $48 \mathrm{~h}$ of incubation.

The SS had higher $(\mathrm{P}<0.05)$ OMD than all the cereal crop residues measured at all the incubation intervals except for CS after $48 \mathrm{~h}$. The STH and MTH had lower ( $<<$ $0.05)$ OMD at $0,4,8$ and $16 \mathrm{~h}$ than the SS and MS, however, the trend reversed after 16 $\mathrm{h}$ with the SS and MS having significantly higher $(\mathrm{P}<0.05) \mathrm{OMD}$ at 24, 48, 72 and 96. The legume straw was found to have higher $(\mathrm{P}<0.05) \mathrm{OMD}$ at all incubation intervals than all the cereal crop residues.

\subsection{Degradability Characteristics}

The results for the rapidly soluble fraction (a), potentially degradable fraction $(b)$, rate of degradation of $b$ fraction (c) and effective degradability (ED) are presented in Table 4 besides the $\mathrm{ED}$ of $\mathrm{DM}$ and $\mathrm{OM}$ at $0.02,0.05$ and 0.08 per hour rates of passage.

The respective DM and OM a fraction for MS were the lowest $(\mathrm{P}<0.05)$ at $11.40 \%$ and $2.80 \%$ amongst all the crop residues. Generally, the DM and OM a fraction was higher $(\mathrm{P}<0.05)$ in legume residue than in the cereal crop residues. The DM and OM $b$ fraction was higher $(\mathrm{P}<0.01)$ in MTH and STH than in the SS and MS. The WS and BS had higher $(\mathrm{P}<0.01) c$ fraction for the DM and OM than the other cereal residues but lower than the legume straw. Similarly, higher DM and OM $b$ fraction was obtained in MTH and STH than in SS and MS.

The respective ED of DM and OM was higher $(\mathrm{P}<0.001)$ at 0.02 and $(\mathrm{P}<0.01)$ at 
Table 3. In situ organic matter degradability of cereals crop residues (\% OMD).

\begin{tabular}{cccccccccc}
\hline \multicolumn{7}{c}{ Time of Incubation in the Rumen (Hrs.) } & & SEM \\
\hline $\begin{array}{c}\text { Crop } \\
\text { residue }\end{array}$ & 0 & 4 & 8 & 16 & 24 & 48 & 72 & 96 & \\
\hline SS & $19.4^{\mathrm{h}}$ & $23.7^{\mathrm{i}}$ & $27.6^{\mathrm{a}}$ & $32.9^{\mathrm{e}}$ & $37.8^{\mathrm{g}}$ & $44.9^{\mathrm{l}}$ & $46.5^{\mathrm{cl}}$ & $46.9^{\mathrm{cl}}$ & 0.27 \\
STH & $13.7^{\mathrm{g}}$ & $17.8^{\mathrm{f}}$ & $20.7^{\mathrm{i}}$ & $34.1^{\mathrm{h}}$ & $40.8^{\mathrm{c}}$ & $50.9^{\mathrm{a}}$ & $55.8^{\mathrm{d}}$ & $55.8^{\mathrm{d}}$ & 0.19 \\
MS & $8.1^{\mathrm{f}}$ & $11.1^{\mathrm{h}}$ & $17.2^{\mathrm{j}}$ & $22.6^{\mathrm{k}}$ & $26.1^{\mathrm{d}}$ & $32.9^{\mathrm{e}}$ & $37.4^{\mathrm{b}}$ & $37.4^{\mathrm{b}}$ & 0.22 \\
MTH & $15.8^{\mathrm{g}}$ & $16.7^{\mathrm{e}}$ & $18.7^{\mathrm{k}}$ & $29.5^{\mathrm{f}}$ & $47.5^{\mathrm{i}}$ & $58.1^{\mathrm{h}}$ & $62.1^{\mathrm{a}}$ & $62.1^{\mathrm{a}}$ & 0.05 \\
CS & $15.5^{\mathrm{g}}$ & $18.9^{\mathrm{d}}$ & $21.7^{\mathrm{e}}$ & $29.8^{\mathrm{f}}$ & $35.6^{\mathrm{h}}$ & $41.6^{\mathrm{m}}$ & $45.0^{\mathrm{ln}}$ & $45.1^{\mathrm{ln}}$ & 0.07 \\
WS & $14.7^{\mathrm{g}}$ & $16.03^{\mathrm{e}}$ & $19.4^{\mathrm{d}}$ & $25.5^{\mathrm{d}}$ & $30.5^{\mathrm{a}}$ & $39.6^{\mathrm{i}}$ & $42.4^{\mathrm{h}}$ & $42.5^{\mathrm{h}}$ & 0.06 \\
BS & $9.6^{\mathrm{f}}$ & $16.3^{\mathrm{e}}$ & $19.9^{\mathrm{d}}$ & $27.2^{\mathrm{g}}$ & $30.3^{\mathrm{a}}$ & $36.1^{\mathrm{j}}$ & $38.5^{\mathrm{bj}}$ & $38.5^{\mathrm{b}}$ & 0.05 \\
LS & $21.1^{\mathrm{h}}$ & $27.6^{\mathrm{c}}$ & $30.9^{\mathrm{c}}$ & $36.6^{\mathrm{c}}$ & $43.3^{\mathrm{f}}$ & $54.2^{\mathrm{k}}$ & $58.8^{\mathrm{k}}$ & $58.8^{\mathrm{k}}$ & 0.07 \\
SEM & 1.07 & 1.22 & 1.14 & 1.33 & 1.76 & 2.16 & 2.28 & 2.279 & \\
\hline
\end{tabular}

Means within the same row with different superscript are significantly different $(\mathrm{P}<0.05)$. Means within the same column with different superscript are significantly different $(\mathrm{P}<0.05) .{ }^{1}$ See text for the description of the crop residues.

Table 4. The DM and OMD characteristics and effective degradability values of crop residues.

\begin{tabular}{|c|c|c|c|c|c|c|c|c|c|c|}
\hline & \multicolumn{8}{|c|}{ Crop Residues ${ }^{1}$} & \multirow[t]{2}{*}{ SEM } & \multirow[t]{2}{*}{ Sig } \\
\hline & SS & $\mathrm{STH}$ & MS & MTH & CS & WS & BS & LS & & \\
\hline \multicolumn{11}{|l|}{$\mathrm{DM}$} \\
\hline$a(\%)$ & $15.78^{\mathrm{a}}$ & $13.4^{\mathrm{b}}$ & $11.4^{\mathrm{c}}$ & $16^{\mathrm{ad}}$ & $16^{\mathrm{ad}}$ & $17.6^{\mathrm{d}}$ & $15.1^{\mathrm{ab}}$ & $23.6^{\mathrm{e}}$ & 0.87 & * \\
\hline$b(\%)$ & $32.2^{\mathrm{b}}$ & $43^{\mathrm{a}}$ & $33.1^{\mathrm{b}}$ & $46.6^{c}$ & $33.4^{\mathrm{b}}$ & $25.2^{\mathrm{d}}$ & $25.3^{\mathrm{d}}$ & $36.5^{\mathrm{e}}$ & 1.84 & * \\
\hline$(a+b) \%$ & $48^{\mathrm{a}}$ & $56.4^{\mathrm{b}}$ & $44.5^{\mathrm{c}}$ & $62.6^{\mathrm{d}}$ & $49.4^{\mathrm{e}}$ & $42.8^{\mathrm{f}}$ & $40.4^{\mathrm{g}}$ & $60.1^{\mathrm{h}}$ & 2.0 & \\
\hline$c$ per h & $0.03^{\mathrm{c}}$ & $0.04^{\mathrm{d}}$ & $0.03^{c}$ & $0.04^{\mathrm{d}}$ & $0.03^{\mathrm{c}}$ & $0.04^{\text {bd }}$ & $0.04^{\mathrm{b}}$ & $0.05^{\mathrm{a}}$ & 0.001 & $* *$ \\
\hline \multicolumn{11}{|l|}{$\mathrm{ED}(\%)$} \\
\hline 0.02 & $35.6^{\mathrm{a}}$ & $42.5^{\mathrm{b}}$ & $31.4^{\mathrm{c}}$ & $47.3^{\mathrm{d}}$ & $36.5^{\mathrm{a}}$ & $34.5^{\mathrm{e}}$ & $31.7^{\mathrm{c}}$ & $49.5^{\mathrm{f}}$ & 1.68 & $* * *$ \\
\hline 0.05 & $29.7^{\mathrm{a}}$ & $33.3^{\mathrm{b}}$ & $25.5^{\mathrm{c}}$ & $37.4^{\mathrm{d}}$ & $30.5^{\mathrm{a}}$ & $29.3^{\mathrm{a}}$ & $26.5^{c}$ & $41.8^{\mathrm{e}}$ & 1.34 & $* *$ \\
\hline 0.08 & $27.2^{\mathrm{a}}$ & $28.7^{\mathrm{a}}$ & $22.9^{\mathrm{b}}$ & $32.5^{\mathrm{d}}$ & $27.9^{\mathrm{a}}$ & $24.8^{\mathrm{ac}}$ & $24.0^{\mathrm{bc}}$ & $37.8^{\mathrm{e}}$ & 1.15 & $* * *$ \\
\hline \multicolumn{11}{|l|}{ OM } \\
\hline$a(\%)$ & $14.9^{\mathrm{a}}$ & $12.3^{\mathrm{b}}$ & $2.8^{\mathrm{c}}$ & $14.04^{\mathrm{a}}$ & $10.4^{\mathrm{d}}$ & $12.4^{\mathrm{b}}$ & $7.2^{\mathrm{e}}$ & $20.4^{\mathrm{f}}$ & 1.27 & * \\
\hline$b(\%)$ & $32.9^{\mathrm{b}}$ & $43.8^{\mathrm{c}}$ & $35.6^{\mathrm{a}}$ & $48.4^{\mathrm{d}}$ & $36^{\mathrm{a}}$ & $30.7^{\mathrm{e}}$ & $31.8^{\text {be }}$ & $38.7^{\mathrm{f}}$ & 1.49 & ** \\
\hline$(a+b)$ & $47.8^{\mathrm{a}}$ & $56.04^{\mathrm{b}}$ & $38.4^{\mathrm{c}}$ & $62.5^{\mathrm{d}}$ & $46.4^{\mathrm{e}}$ & $43.04^{\mathrm{f}}$ & $39.0^{\mathrm{g}}$ & $59.02^{\mathrm{h}}$ & 2.22 & \\
\hline$c$ perh & $0.03^{\mathrm{a}}$ & $0.04^{\mathrm{b}}$ & $0.02^{\mathrm{c}}$ & $0.04^{\mathrm{b}}$ & $0.03^{\mathrm{a}}$ & $0.03^{\mathrm{d}}$ & $0.03^{\mathrm{d}}$ & $0.05^{\mathrm{e}}$ & 0.002 & $* *$ \\
\hline \multicolumn{11}{|l|}{$\mathrm{ED}(\%)$} \\
\hline 0.02 & $35.2^{\mathrm{a}}$ & $41.9^{\mathrm{b}}$ & $23.6^{\mathrm{c}}$ & $46.6^{\mathrm{d}}$ & $32.1^{\mathrm{e}}$ & $32.1^{\mathrm{e}}$ & $27.3^{\mathrm{f}}$ & $47.7^{\mathrm{d}}$ & 2.13 & $* * *$ \\
\hline 0.05 & $29.1^{\mathrm{a}}$ & $32.6^{\mathrm{b}}$ & $17.2^{\mathrm{c}}$ & $36.2^{\mathrm{d}}$ & $25.6^{\mathrm{e}}$ & $25.8^{\mathrm{e}}$ & $20.7^{\mathrm{f}}$ & $39.6^{\mathrm{g}}$ & 1.83 & ** \\
\hline 0.08 & $26.4^{\mathrm{a}}$ & $27.8^{\mathrm{a}}$ & $14.6^{\mathrm{b}}$ & $31.1^{\mathrm{d}}$ & $22.7^{\mathrm{c}}$ & $22.8^{\mathrm{c}}$ & $17.7^{\mathrm{f}}$ & $35.2^{\mathrm{e}}$ & 1.64 & $* * *$ \\
\hline
\end{tabular}

Means within the same row with different superscript are significantly different $\left(\mathrm{p}<{ }^{*} 0.05,{ }^{* *} 0.01\right.$ or $\left.{ }^{* * *} 0.001\right)$; SEM $=$ Standard Error Mean, Sig. $=$ significance level $\left({ }^{*} 0.05,{ }^{* *} 0.01\right.$ and $\left.{ }^{* *} 0.001\right) .{ }^{1}$ See text for the description of the crop residues. 
0.05 rates of passage for STH and MTH than SS and MS. The BS and MS had the lowest ED MD at $0.02(\mathrm{P}<0.001)$ and $0.05(\mathrm{P}<0.01)$, while $\mathrm{LS}$ had the highest.

\section{Discussion}

\subsection{Chemical Composition}

The chemical composition results of cereal and legume straw obtained in this study are in agreement with those presented in [4] and [5] whose studies found higher levels of $\mathrm{CP}$ and lignin and low NDF and ADF in legumes than in cereal crop residues. The results for the EE and OM obtained in this study match those reported in [4] and [5] studies for the WS and BS. The CP, EE OM, NDF and ADF values obtained from SS and $\mathrm{CS}$ in the current study are consistent with those reported by [4]. Results for the CP, $\mathrm{CF}, \mathrm{NDF}, \mathrm{ADF}, \mathrm{ADL}$ and ash content of LS reported here are similar to those determined by [21]. The SS residue OM value presented in [7] is higher than that obtained in the current study however the CP content is in agreement. Generally, chemical composition values reported for cereal and legume crop residues [4] [22] are consistent and within the ranges of those obtained in this study.

The small variations that exist in the chemical composition of different crop residues realized in this study and those presented in other studies can be explained by the differences in varieties, proportion of botanical fractions, growing conditions (geographic, seasonal variations, climatic conditions and soil characteristics), extent of foreign materials and impurities such as soil contamination, different measuring methods and laboratories procedures [11] [23] [24] [25] [26] [27].

\subsection{In Situ Degradability Parameters and Effective Degradability}

The values of DM a fraction and $c$ parameter for the SS obtained in the present study correspond to those reported in [6] and [11]. However, in the work done by [11] for the SS, the $b$ fraction and ED were higher than those obtained in the present study. [9] and [28] reported lower values of DM and OM $a, c$ fraction and higher $b$ fraction for SS than those obtained in this study. However, the value of the degradable fraction $(a+b)$ for DM for the SS was similar to that determined in the Hamed et al. studies. It is [11] who observed that the nutritional characteristics of SS varied widely and could be explained by differences in the proportion and chemical composition of the botanical fractions.

The values obtained for the DM $b$ fraction and $c$ for CS in this study are similar to those reported in Silva et al. (2008) but results from the two studies differ in that the $a$ fraction is lower in the current study than in [10]. Further, [10] pointed out that the high value for the a fraction of CS in their study could be explained by the lower NDF content across four stage of maturity tested.

The DM disappearance at $0 \mathrm{~h}$ incubation time for CS reported by [8] is lower than the value determined in this study which could be due to higher NDF content of the whole CS evaluated in the [8] study. The degradation parameters $a, b$, and $c$ fraction and the ED at all passage rates of DM for WS are in agreement with those presented in [29]. Besides, the potentially degradable $(a+b)$, and $c$ fraction as well as the ED at 0.02 and 0.05 passage rates of DM for WS were identical to those reported in [30]. However, 
the value of $a$ fraction of DM for WS is lower and that of $b$ higher in the studies of [31] and [30] than in the current study. The OM $a$ fraction for WS is similar to that reported by [30] while $b, c$ fraction and ED are lower in the present study. The DM $a, b$ fractions for LS are similar to those obtained by [32] with the exception of the $(a+b)$ which was higher.

The DM $c$ fraction and ED values for BS obtained in the current study are similar to those reported by [33] however the $a$ fraction is higher while $b$ is lower. The values of $b$ fraction and ED of DM for BS are different from those reported by [31] and [30]. The $\mathrm{OM} a, b$ fractions and ED for BS are lower than those reported by [30]. The differences in the values presented in the other studies and those obtained in the current study could be explained by probable use of different crop varieties evaluated in the studies. The potential differences as a result of use of different varieties in degradability tests was confirmed by the study carried out by [34] who detected differences in in situ DM degradability in WS of different varieties. [35] also reported differences in in situ degradability parameters between straw varieties. The differences could also be attributed to differences in the proportion of leaf and stem, animal and diet effects, particle size, incubation characteristics, rumen conditions and microbial contamination [36].

Other factors that could account for the differences between published values for different crop residues and those obtained in the current study would include different chemical composition, leaves to stems proportion, method of feedstuff evaluation (in vivo, in vitro and in situ), straw varieties, maturity and impurity as well as technical variation such bag pore size, sample size, washing procedures, grinding size, diet of experimental animal, species of animal, sample preparation, incubation time and washing method [24] [25] [26] [27] [34] [37].

\section{Conclusion}

There are differences in chemical and nutritive characteristics amongst cereals and between cereal and legume crop residues found in Eritrea as hypothesized in this study. The ED of DM and OMD values were higher for legume residue than in the cereal crop residues. Similar trend was observed in the values of parameters $a, b,(a+b)$ and $c$ which were generally high for the legume than cereal crop residues. In all cases, the legume residue in situ DM and OM degradability value was higher than all cereal crop residues except the DM and OM in MTH after 24 and $72 \mathrm{~h}$ respectively. The crop residues produced in Eritrea compare favorably with those produced in other countries in terms of nutrients and degradability implying that they have high potential for use in supplementing grazed livestock. Alternative treatments methods exist that can be applied on the residues so as to release more nutrients. For the findings from the current study to be useful in evaluating potential use of the crop residues tested in feeding grazing livestock, there is a need to determine the effect of implementing different crop residues treatments approaches to improve their nutritional value. This should be coupled with feeding trial to ascertain that the nutrients released are actually taken up by animals for beneficial biological functions such as weight gain in growing stock.

\section{Acknowledgements}

The authors would like to recognize Japan International Corporation Agency (JICA) 
for provision of financial support for this study and Hamelmalo Agricultural College (HAC) of Eritrea for granting the first author permission to participate in the research.

\section{References}

[1] Kosgey, I.S., van Arendonk, J.A. and Baker, R.L. (2003) Economic Values for Traits of Meat Sheep in Medium to High Production Potential Areas of the Tropics. Small Ruminant Research, 50, 187-202. https://doi.org/10.1016/S0921-4488(03)00102-0

[2] Gicheha, M.G., Edwards, G.R., Bell, S.B. and Bywater, A.C. (2014) Embedded Risk Management in Dryland Sheep Systems: II. Risk Analysis. Agricultural Systems, 124, 1-11. https://doi.org/10.1016/j.agsy.2013.05.001

[3] FAO (2006) Food and Agricultural Organization of the United Nation. Suttie. J.M. and Reynolds, S.G., Eds.

[4] Sultan, S., Kushwaha, B.P., Nagl, S.K., Mishra1, A.K., Bhattacharya, S., Gupta, P.K. and Singh, A. (2011) In Vitro Methane Emission from Indian Dry Roughages in Relation to Chemical Composition. Current Science, 101, 57-65.

[5] Lopez, S., Davies, D.R., Giraldez, F.J., Dhanoa, M.S., Dijkstra, J. and France, J. (2005) Assessment of Nutritive Value of Cereal and Legume Straws Based on Chemical Composition and in Vitro Digestibility. Journal of Science Food and Agriculture, 85, 1550-1557. https://doi.org/10.1002/jsfa.2136

[6] Abbator, F.I., Kibon, A. and Mohammed, I.D. (2002) Nutrient Composition and Rumen Degradation of Some Feedstuffs in the Semi-Arid Region of Nigeria. Journal of Sustainable Agriculture and the Environment, 4, 158-164.

[7] Savadogoa, M.G., Zemmelink, B. and Nianogoc, A.J. (2002) Effect of Selective Consumption on Voluntary Intake and Digestibility of Sorghum (Sorghum bicolor L. Moench) Stover, Cowpea (Vigna unguiculata L. Walp.) and Groundnut (Arachis hypogaea L.) Haulms by Sheep. Animal Feed Science and Technology, 84, 265-277. https://doi.org/10.1016/S0377-8401(00)00115-2

[8] Li, H.Y., Xu, L., Liu, W.J., Fang, M.Q. and Wang, N. (2014) Assessment of the Nutritive Value of Whole Corn Stover and Its Morphological Fractions. Asian Australasian Journal of Animal Sciences, 27, 194-200. https://doi.org/10.5713/ajas.2013.13446

[9] Hamed, A.H. and Elimam, M.E. (2008) Degradation of Sorghum Stover Treated with Rabaa Ash Alkali in the Rumen of Nubian Goats Gezira. Journal of Agricultural Science, 16, 2-7.

[10] Silva, L.F., Prada, E., Laerte, D.C., Roma, L.C., Rodrigues, A.C. and Machado, P.F. (2008) In Situ Degradability of Corn Stover and Elephant-Grass Harvested at Four Stages of Maturity. Science and Agriculture, 65, 595-603. https://doi.org/10.1590/S0103-90162008000600005

[11] Elseed, A.M., Niemat, A.F., Nor Eldaim, I. and Amasaib, E.O. (2007) Chemical Composition and in Situ Dry Matter Degradability of Stover Fractions of Five Sorghum Varieties. Journal of Applied Sciences Research, 3, 1141-1145.

[12] Eyob, H., Njonge, F.K., Goitom, A. and Gicheha, M.G. (2016) Production and Potential Utilization of Crop Residues and Agro-Industrial By-Products in Ruminant Nutrition in Eritrea. RUFORUM Biennial Conference: Linking Universities with Private Sector, Governments and Other Stakeholders in Support of Agricultural Development in Africa, Cape Town, 17-21 October 2016 (in Press).

[13] Ørskov, E.R., Reid, G.W. and Kay, M. (1987) Prediction of Intake by Cattle from Degradation Characteristics of Roughages. Animal Production, 46, 29-34. https://doi.org/10.1017/S000335610000307X

[14] Shen, H.S., Sundstøl, F., Eng, E.R. and Eik, L.O. (1999) Studies on Untreated and UreaTreated Rice Straw from Three Cultivation Seasons: 3. Histological Investigations by Light and Scanning Electron Microscopy. Animal Feed Science and Technology, 80, 151-159. 
https://doi.org/10.1016/s0377-8401(99)00045-0

[15] Preston, T.R. (1986) Better Utilization of Crop Residues and By-Products in Animal Feeding: Research Guideline 2. A Practical Manual for Research Works. FAO Animal Production and Health Paper 50, 2-10.

[16] Association of Official Analytical Chemists (AOAC) (1990) Official Methods of Analysis. 15th Edition, Association of Official Analytical Chemists, Washington DC.

[17] Van Soest, P.J., Robertson, J.D. and Lewis, B.A. (1991) Methods for Dietary Fibre, Neutral Detergent Fibre and Non-Starch Polysaccharides in Relation to Animal's Nutrition. Journal of Dairy Science, 74, 3583-3597. https://doi.org/10.3168/jds.S0022-0302(91)78551-2

[18] Ørskov, E.R., Hovell F.D.D. and Mould, F. (1980) The Use of the Nylon Bag Technique for the Evaluation of Feedstuffs. Tropical Animal Production, 5, 195-213.

[19] Federation of Animal Science Societies (1999) Guide for the Care and Use of Agricultural Animals in Agricultural Research and Teaching. Committees to Revise the Guide for the Care and Use of Agricultural Animals in Agricultural Research and Teaching, Savory.

[20] Bhargava, P.K. and Ørskov, E.R. (1987) Manual for the Use of Nylon Bag Technique in the Evaluation of Feedstuffs. Rowett Research Institute, Aberdeen.

[21] Abreu, J.M. and Bruno-Soares, A.M. (1998) Characterization and Utilization of Rice, Legume and Rape Straws. In: Antongiovanni, M., Ed., Exploitation of Mediterranean Roughage and By-Products, CIHEAM, Zaragoza, 39-51.

[22] Theander, O. and Aman, P. (1984) Anatomical and Chemical Characteristics. In: Sundstol, F. and Owen, E., Eds., Straws and Other Fibrous Byproducts as Feed, Elsevier, Amsterdam, 45-78.

[23] Maheri-Sis, N., Chamani, M., Sadeghi, A., Mirza-Aghazadeh, A. and Safaei, A. (2007) Nutritional Evaluation of Chickpea Wastes for Ruminants Using in Vitro Gas Production Technique. Journal of Animal and Veterinary Advances, 6, 1453-1457.

[24] Bampidis, V.A. and Christodulou, V. (2011) Chickpeas (Cicer artietinum L.) in Animal Nutrition. Animal Feed Science Technology, 168, 1-20.

https://doi.org/10.1016/j.anifeedsci.2011.04.098

[25] Kafilzadeh, F. and Maleki, E. (2011) Chemical Composition in Vitro Digestibility and Gas Production of Straws from Different Varieties and Accessions of Chickpea. Journal of Animal Physiology and Animal Nutrition, 96, 111-118. https://doi.org/10.1111/j.1439-0396.2011.01131.x

[26] Maheri-Sis, N., Aghajanzadeh-Golshani, A., Cheraghi, H., Ebrahimnezhad, Y., Ghalehkandi, J.G. and Asaadi-Dizajii, A. (2011) Dry Matter Degradation and Metabolizable Energy of Chickpea (Cicer arietinum) Straw in Ruminants. Research Journal of Biological Sciences, 6 , 635-638. https://doi.org/10.3923/rjbsci.2011.635.638

[27] Aghajanzadeh-Golshani, A., Maheri-Sis, N., Baradaran-Hasanzadeh, A., Asadi-Dizaji, A., Mirzaei-Aghsaghali, A. and Dolgari-Sharaf, J. (2012) Determining Nutrients Degradation Kinetics of Chickpea (Cicer arietinum) Straw Using Nylon Bag Technique in Sheep. Open Veterinary Journal, 2, 54-57.

[28] Hamed, A.H. and Elimam, M.E. (2009) Effect of Steam Pressure and Duration on the Nutritive Value of Sorghum Stover and Millet Straw in the Sudan Gezira. Journal of Agricultural Science, 17, 59-62.

[29] Shawrang, P., Sadeghiand, A. and Ahmadpanah, J. (2013) Ruminal Degradation Kinetics of Wheat Straw Irradiated by High Doses of Electron Beam. Iranian Journal of Applied Animal Science, 3, 25-29.

[30] Nasehi, M., Torbatinejad, N., Zerehdaran, S. and Safaei, A. (2014) Effect of (Pleurotus florida) Fungi on Chemical Composition and Rumen Degradability of Wheat and Barley Straw. Iranian Journal of Applied Animal Science, 4, 257-261. 
[31] Kamalak, A., Canbolat, O., Gurbuz, Y. and Ozay, O. (2005) Comparison of in Vitro Gas Production Technique with in Situ Nylon Bag Technique to Estimate Dry matter Degradation. Czech Journal of Animal Sciences, 50, 60-67.

[32] Bruno-Soaresa, A.M., Abreua, J.M., Guedes, C.V. and Dias-da-Silvab, A.A. (2000) Chemical Composition, DM and NDF Degradation Kinetics in Rumen of Seven Legume Straws. Animal Feed Science and Technology, 83, 75-80. https://doi.org/10.1016/S0377-8401(99)00113-3

[33] Trujillo, A.I., Marichal, M.J. and Carriquiry, M. (2010) Comparison of Dry Matter and Neutral Detergent Fiber Degradation of Fibrous Feedstuffs as Determined with in Situ and in Vitro Gravimetric Procedures. Animal Feed Science and Technology, 161, 49-57. https://doi.org/10.1016/j.anifeedsci.2010.08.001

[34] Anjum, M.I., Ghazanfar, S. and Begum, I. (2014) Nutritional Composition of Wheat Grains and Straw Influenced by Differences in Varieties Grown under Uniform Agronomic Practices. International Journal of Veterinary Science, 3, 100-104.

[35] Ørskov, E.R., Shand, W.J., Tedesco, D. and Morrice, L.A. (1990) Rumen Degradation of Straw 10 Consistency of Differences in Nutritive Value between Varieties of Cereal Straws. Animal Production, 51, 155-162. https://doi.org/10.1017/S0003356100005250

[36] Ramanzin, M., Bailoni, L. and Schiavon, S. (1997) Effect of Forage to Concentrate Ratio on Comparative Digestion in Sheep, Goat and Fallow Deer. Animal Science, 64, 163-170. https://doi.org/10.1017/S1357729800015678

[37] Chumpawadee, S. (2009) Degradation Characteristics of Tomato Pomace, Soybean Hull and Peanut Pod in the Rumen Nylon Bag Technique. Journal of Nutrition, 8, 1717-1721. https://doi.org/10.3923/pjn.2009.1717.1721

\section{Submit or recommend next manuscript to SCIRP and we will provide best service for you:}

Accepting pre-submission inquiries through Email, Facebook, LinkedIn, Twitter, etc. A wide selection of journals (inclusive of 9 subjects, more than 200 journals) Providing 24-hour high-quality service User-friendly online submission system Fair and swift peer-review system Efficient typesetting and proofreading procedure Display of the result of downloads and visits, as well as the number of cited articles Maximum dissemination of your research work

Submit your manuscript at: http://papersubmission.scirp.org/

Or contact ojas@scirp.org 